\title{
Managerial Ownership, Board of Directors, Equity-based Compensation and Firm Performance: A Comparative Study between France and the United States
}

\author{
Mehdi Bouras \\ Higher Institute of Business Administration of Gafsa, Tunisia \\ Laboratory of Risk Management and Research in Accounting and Finance RIM-RAF, Manouba University \\ Mohamed Imen Gallali \\ Higher Business School of Tunis, Tunisia \\ Laboratory of Risk Management and Research in Accounting and Finance RIM-RAF, Manouba University
}

Doi:10.5901/mjss.2017.v8n1p78

\section{Abstract}

The aim of this comparative study between the French and American markets, characterized by a different ownership structure is to examine the relationship between managerial ownership, the board of directors, the equity-based compensation and corporate performance. Regardless of the selected sample, we found on the one hand, a non-linear relationship between managerial ownership and firm performance and on the other hand, in the case of managerial entrenchment board of directors is a substitute for managerial ownership to solve the agency problem. In addition, stock-based compensation is non-linear function with managerial ownership, contrary to previous studies that assume a monotonous or non-significant relationship. The hypothesis of endogeneity is valid only in the American case. This result leads us to believe that the U.S. CEO has a preference to hold a large percentage of shares of firms that generate a good performance to neutralize capital market monitoring. Our study is exclusive in terms of the effect of managerial ownership on corporate performance in terms of comparison between two markets, characterized by a difference in ownership structure. We determine the impact of equity compensation on the one hand, the managerial ownership where all the studies assume either a monotone or neutral relationship between these two variables and on the other hand, the effect of board in the alignment or managerial entrenchment cases.

Keywords: Agency Theory, Managerial Entrenchment, Managerial ownership, Firm Performance, Board, Equity Compensation.

\section{Introduction}

Discussion of previous research on the impact of managerial ownership, as an incentive mechanism and its effects on the performance of the company, primarily focuses on agency problems resulting from the separation of ownership and control (Berles and Means, 1932) which is due to the divergence of interests between managers and shareholders (Jensen and Meckling, 1976).

According to Drakos and Bekiris (2010), agency problems have a negative impact on the value of the company while managerial ownership is a potential solution to this conflict of interests. However, according to Morck et al. (1988) and Denis et al. (1997) a high percentage of shares held by the manager, results in a reduction in the effectiveness of external governance mechanisms (capital market monitoring). A large number of previous studies shows that there is a non-linear relationship between managerial ownership and firm performance (Morck et al. (1988), Davies et al. (2005), $\mathrm{Ng}$ (2005), Cheng et al. (2012) Florackis et al. (2009) and Ruan et al. (2011)).

According to Fama and Jensen (1983), Yermack (1996) and Cheng et al. (2012), the board is considered a source mechanism for reducing agency conflicts between the CEO and shareholders. Therefore, referring to the substitution hypothesis of governance mechanisms, we expect that the board of directors' effectiveness can affect the relationship between managerial ownership (alignment or entrenchment) and firm performance. 
A comparative study between the American and French markets is interesting since, the latter is characterized by a concentrated ownership structure whereas in the US case the firm's ownership structure is much dispersed.

First, we perform an analysis on the relationship between performance and managerial ownership to determine the inflection points that correspond to the convergence or divergence of interests for both markets.

Then, referring to the turning points, we perform a piecewise regression to determine if the board is a substitute for managerial ownership in the case of managerial entrenchment.

Next, on the one hand, given the importance of pay equity as a component alignment of interests between the agent and the principal and on the other hand, referring to the study of Cheng et al. (2012) who try to explain the relationship between the total compensation received by the manager, the managerial ownership and board at once. We attempt to determine the relationship that may exist between this component of compensation and effectiveness of the board in the case of convergence or divergence of interests.

Finally, Demsetz and Lehn (1985) suggest that managerial ownership is determined endogenously as a simultaneous equation where analysis is carried to determine the direction of causality between the managerial property and firm performance for both cases.

Our study provides a contribution to the literature on several aspects.

First, on the level of the sample, we try to compare the two markets, which are characterized by differences in ownership structure. Indeed, most studies focus on the U.S. and UK cases where firm's ownership structure for these two cases is much dispersed and they ignore the other markets, which are characterized by a more concentrated ownership structure and a strong presence of institutional investors such as the French case.

Our study is exclusive in terms of the effect of managerial ownership on corporate performance in terms of comparison between two markets, characterized by a difference in ownership structure.

Second, there is an increasing number of studies on the impact of the board on firm performance as Vafeas and Theodorou (1998), Jackling and Johl (2009) and Pathan and Faff (2013), but they have not held for the presence of alignment or entrenchment effect, except the investigation of $\mathrm{Ng} \mathrm{(2005)}$ and Cheng et al. (2012). They tested the combined effect of the board and managerial ownership in the Chinese context that is characterized by a high concentration and a strong presence of the state as opposed to French and American cases where the state is not a potential shareholder.

In addition, the study by Cheng et al. (2012) includes a score board to measure its effectiveness, it includes only the size of the board, the presence of independent directors and CEO duality. We will integrate in the board score other variables that are important for the proper functioning of this mechanism such as the presence of women on the board, the percentage of shares held by directors, the presence of the remuneration committee...

Third, referring to the work of Cheng et al. (2012) where they have linked the importance of compensation received by the manager and the combined effect of the board and managerial ownership. Our study attempts to determine the impact of equity compensation on the one hand, the managerial ownership where all the studies assume either a monotone or neutral relationship between these two variables and on the other hand, the effect of board in the alignment or managerial entrenchment cases.

Fourth, from the analysis of the simultaneous equations, we try to determine the direction of causality between managerial ownership and firm performance for both contexts and try to explain the difference, if there is any, in the results.

The Following study is organized as follows, first, we present a literature review and research hypotheses (section 2), then we present the sample and data sources (section 3) after that, we expose the model used (Section 4), then, we interpret the results (section 5), and determine the direction of causality between managerial ownership and firm performance (Section 6) and finally, we conclude this study (section 7).

\section{Literature Review and Research Hypotheses}

\subsection{Managerial ownership / Performance}

Theoretically, two contradictory hypothesis explain the duality firm performance / managerial ownership.

The hypothesis of convergence of interest where DeAngelo and DeAngelo (1985) suggest that the high managerial shareholding can solve the problem of asymmetric information related to investments. Therefore, based on this assumption, there is a positive relationship between the proportion of shares held by the manager and firm performance.

Instead, according to the theory of entrenchment, we expect a negative relationship between these two variables. Fama and Jensen (1983) suggest that a large managerial shareholding can generate additional costs indeed, in this 
situation the manager has a significant voting power that isolates the shareholders of exercising effective control over the management of the CEO (Chen et al. 2012).

In conclusion, the impact of managerial ownership on firm performance is a double-edged sword (Alignment of interests vs. Managerial entrenchment) (Hu and Izumida (2008)).

At the empirical study, the results are mitigated, but they converge on the finding of a non-linear relationship between two variables such as inverted U-shaped as the work of (McConnell and Servaes (1990), Hu and Zhou (2008) and Chen et al. (2012)) or cubic type (N Form) such as studies by (Short and Keasey (1999), Ruan et al. (2011) and Cheng et al. (2012)) or quadratic relation as the study of (Cui and Mak (2002) and McConnell and Servaes (1990)) or quantum relation such as the study of (Davies et al.(2005), Florackis et al. (2009)).

From the previous, we try to test the following hypothesis:

$\mathrm{H} 1$ : There exists a non-linear relationship between managerial ownership and firm performance.

\subsection{Managerial ownership / Performance / Board of directors}

According to Lasfer (2006), entrenchment hypothesis predicts that the manager who holds a high percentage of managerial ownership can dominate the board of directors and will therefore tend to reduce his role of monitoring for example by reducing the proportion of independent directors or combining functions of the CEO and board chairperson.

As we have previously developed, we expect a negative relationship between managerial ownership and corporate performance in the case of managerial entrenchment.

From the above and with reference to the study of $\mathrm{Ng}$ (2005), Lasfer (2006) and Cheng et al. (2012) we relate the performance of the company both, with the managerial ownership and the board characteristics.

Thus, we verify the following hypothesis:

$\mathrm{H} 2$ : Firm performance is affected by the combined impact of managerial ownership and effectiveness of the board.

\subsection{Managerial ownership / Board of directors / Managerial compensation}

According to Ozdemir and Upneja (2012), the board of directors is a supervisory mechanism that monitors decisions by the manager and protects the rights of shareholders. In addition, to its impact on the performance of companies, it is responsible for monitoring the excessive compensation received by the manager.

Core et al. (1999) and Bebchuk and Fried (2004) suggest that managerial entrenchment makes it more difficult for shareholders to replace the manager and more, it facilitates the opportunistic behavior of the latter, especially at the level of compensation.

Holderness and Sheehan (1991) and Ozkan (2007) suggest that the remuneration of the manager in the form of stock options and restricted stock is higher in the case of weak governance firms.

In addition, Weir et al. (2001) suggest that equity-based compensation is positively associated with the managerial entrenchment.

Several studies, such as Lewellen et al. (1997), Matsunaga (1995) and Mehran (1995) examine the relationship between the award equity-based compensation and managerial ownership.

According to Mehran (1995), there exists an inverse relationship between managerial ownership and agency costs, while the granting of stock options or restricted stock may be a potential solution to align the interests of manager with those of shareholders.

Based on the work of Cheng et al. (2012), who try to determine if the board is a substitute for managerial ownership in the case of managerial entrenchment to limit excessive managerial compensation.

In addition, given the relationship between on the one hand, the equity-based compensation and board and, on the other hand, between the stock-based compensation and managerial ownership.

We test the following hypothesis:

H3: The equity-based compensation is influenced by a combined effect of managerial ownership and effectiveness of the board.

\section{Selected Sample and Data Sources}

In terms of the American case, the initial sample is composed of the 300 largest companies, selected according to the criteria of market capitalization in the S\&P500 index.

For French firms, the initial sample consists of all companies belonging to the CAC All Tradable Index. 
On the one hand, we have eliminated financial firms because they represent a different financial structure compared to other types of firms, thus 48 firms for the American case and 36 companies in the French case. On the other hand, we eliminated the companies where the data are not available, respectively 49 and 55 U.S. and French firms. The final sample represents 203 U.S. companies and 159 French companies, including a 9 years period from 2002 to 2010.

We did use two main data sources, Compustat North America and Compustat Global database for financial variables, and annual reports for data related to governance and ownership structure of companies that we have collected manually. In addition, we used in the U.S case Thomson Reuters Institutional Ownership and Compustat ExecuComp databases to collect respectively data involving to the CEO compensation and the percentage of shares held by institutional investors.

\section{Presentation of the Selected Models}

\subsection{Managerial ownership / Performance}

As we reported above, we provide a non-linear relationship between managerial ownership and corporate performance, but the problem is to identify which type relationship is applicable for U.S. and French markets (square, cubic, quadratic or quantum). In addition, the two cases are characterized by a different ownership structure, including the managerial ownership. Therefore, we will determine for each of the two cases the nature of the relationship which best explains these two variables.

The model to be tested is as follows, based on the study of Davies et al. (2005), Florackis et al. (2009) and Chen et al. (2012).

$$
\text { Tobin's } Q={ }^{\alpha_{0}+\sum_{i=1}^{k} \alpha_{i} \cdot \text { Manag.Owner }{ }^{i}}+\text { Cont.Var }+\xi ; k=\{1,2,3,4,5\}
$$

With:

- Tobin's Q: A proxy for measuring firm's performance where it has been used in several previous studies such as (Cui and Mak (2002), Davies et al (2005) and Hu and Izumida (2008). It is measured as follows:

Tobin's $Q=\frac{\text { MEV-BVE+BVTA }}{\text { BVTA }}$

Where:

- MEV: Market equity value;

- BVE: Book value of equity;

- BVTA: Book value of total assets;

- Manag.Owner: Managerial ownership is measured by the percentage of shares held by the manager;

- Cont. Var. The control variables that could affect the firm's performance and they are derived from previous work. We were referring to studies Morck el al. (1988) and Maury (2006) we use the following variables:

- Size: The size of the firm is measured by the natural logarithm of total assets;

- Lev: The debt of the firm is measured by the ratio of total debt to total assets;

- Volat: Equity volatility is measured by the standard deviation of stock returns.

\subsection{Managerial ownership / Performance / Board of directors}

To examine the relationship between the effectiveness of the board and the performance of the company considering the effect of managerial ownership (interest alignment or entrenchment). We determine the extremum point (maximum or minimum) that correspond to the convergence of interest or managerial entrenchment.

Concerning the American (French) case, the critical points are of $11.0895 \% 48.3692 \%$ and $61.5412 \%(57,538 \%)$, representing the percentage of shares held by the manager ${ }^{1}$.

We adapt a model of piecewise linear regression to highlight the effect of non-linearity of the managerial ownership, in accordance with the same approach in the studies of Morck et al. (1988), Hess et al. (2010), Ruan et al. (2011) and Cheng et al. (2012). More precisely, the managerial ownership variable (.manag prop) is divided as follows:

For the French case:

Manag. Owne $_{\mathrm{A}}= \begin{cases}\text { Manag. Owner } & \text { if Manag. Owne }<57.5383 \% \\ 57.5383 \% & \text { if Manag.Owne } \geq 57.5383 \%\end{cases}$

\footnotetext{
${ }^{1}$ The choice of the nature of the model and results are discussed in section interpretation of results
} 
Manag. Owne $_{\mathrm{B}}= \begin{cases}0 & \text { if Manag. Owner }<57.5383 \% \\ \text { Manag. Owne }-57.5383 \% & \text { if Manag. Owne } \geq 57.5383 \%\end{cases}$

For the American case:

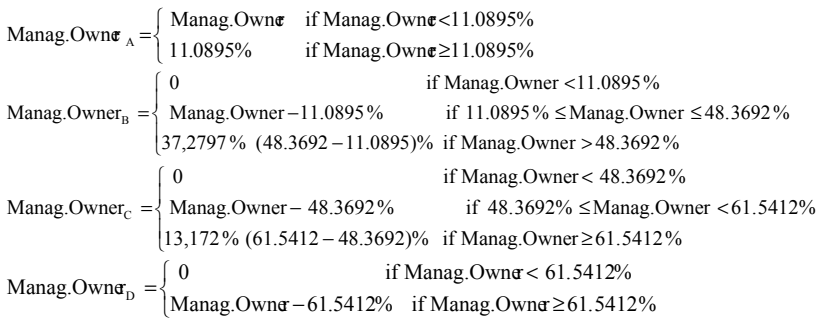

Therefore, the piecewise regression model is estimated for the following two cases:

France:

Tobins $Q=\beta_{0}+\beta_{1}$ Manag.Owne ${ }_{A}+\beta_{2}$ Manag.Owne ${ }_{B}+\beta_{3} B d$ Index $+\beta_{4}$ Manag. Owne $e_{A} *$ BdIndex

$+\beta_{5}$ Manag. Owne ${ }_{B} *$ Bd.Index $+\beta_{6}$ Size $+\beta_{7}$ Lev $+\beta_{8}$ Volat $+\beta_{9}$ Size* BdIndex

$+\beta_{10}$ Lev*BdIndex $+\beta_{11}$ Volat*BdIndex $+\xi$

United States:

Tobin's $Q=\beta_{0}+\beta_{1}$ Manag. Owne $\boldsymbol{A}_{\mathrm{A}}+\beta_{2}$ Manag. Owne $_{\mathrm{B}}+\beta_{3}$ Manag.Owne $\mathrm{C}_{\mathrm{C}}+\beta_{4}$ Manag.Owne $\mathrm{D}_{\mathrm{D}}$ $+\beta_{5}$.Bd.Index $+\beta_{6}$ Manag. Owne ${ }_{\mathrm{A}} *$ Bd.Index $+\beta_{7}$ Manag.Owne $\boldsymbol{B}_{\mathrm{B}} *$ Bd.Index $+\beta_{8}$ Manag. Owne ${ }_{\mathrm{C}} *$ Bd.Index $+\beta_{9}$ Manag. Owne ${ }_{\mathrm{D}} *$ Bd.Index $+\beta_{10}$ Size $+\beta_{11}$ Lev $+\beta_{12}$ Volat $+\beta_{13}$ Size $*$ Bd.Index $+\beta_{14}$ Lev $*$ Bd.Index $+\beta_{15}$ Volat*Bd.Index $+\xi$

Where:

- The Tobin's Q, Manag.Owner, Manag.Owner, Manag.Ownerc, Manag.Ownerd, Size, Lev and Volat are previously defined.

For variable (Bd.Index), it is the score board where some authors such as (Klapper and Love (2004) and Bhagat and Bolton (2008)) use this measure as a proxy for the effectiveness of the board. It includes several variables related to the characteristics of the board that ensure a good functioning of this mechanism (board size, the presence of independent directors, the compensation committee ....).

\subsection{Managerial ownership / Board of directors / Managerial equity compensation}

To investigate the relationship between the effectiveness of the board and the equity-based compensation received by the executive in the case of alignment of interest or entrenchment. We refer to the study of Cheng et al. (2012) which is to our knowledge the only study that tested the effectiveness of the board in the control of executive compensation for both hypotheses (Alignment vs. entrenchment).

The model to be estimated is as follows:

For the French case:

Equity.Comp $=\varphi_{0}+\varphi_{1}$ Manag.Owner $_{\mathrm{A}}+\varphi_{2}$ Manag.Owner $_{\mathrm{B}}+\varphi_{3}$. Bd.Index $+\varphi_{4}$ Manag.Owner $_{\mathrm{A}} *$ Bd.Index $+\varphi_{5}$ Manag.Owner ${ }_{\mathrm{B}} *$ Bd.Index $+\varphi_{6}$ Size $+\varphi_{7}$ Lev $+\varphi_{8}$ Tobin's $Q+\varphi_{9}$ Owner.Concent $+\varphi_{10}$ Institu $+\varphi_{11}$ Size $*$ Bd.Index $+\varphi_{12}$ Lev $*$ Bd.Index $+\varphi_{13}$ Tobin's $Q * B d . I n d e x$ (5)

Where: $+\varphi_{14}$ Owner.Concent $*$ Bd.Index $+\varphi_{15}$ Institu $*$ Bd.Index $+\xi$

- Equity.Comp: The natural logarithm of $(1+$ values of stock options and restricted stock received by the manager in year t) ${ }^{2}$. (Brown and Lee (2010) and Guillet et al. (2012)).

- Manag.Owner, Manag.Owner, Manag.Owner, Manag.Owner, Bd.Index, and Tobin's $Q$ are previously defined.

- We also include control variables that have been found in prior research to be associated with decision of award equity-based compensation (Yermack (1995), Tzioumis (2008) and Van Essen (2012)).

- Firm size (Size): Natural logarithm of total assets;

- Firm leverage (Lev): The ratio of total debt to total assets;

- Ownership concentration (Owner.Concent): The percentage of shares held by the top three shareholders;

- Institutional investors (Institu): The percentage of shares held by institutional investors.

${ }^{2}$ Calculated using the Black and Scholes' formula (1973) taking into account of future payments of dividends 


\section{Interpretation of Results}

\subsection{Descriptive Analysis}

Table 1 presents descriptive statistics for variables used to test the relationship between managerial ownership, board of directors' monitoring role and equity compensation received by the manager.

Table 1: Descriptive statistics

\begin{tabular}{|c|c|c|c|c|c|c|}
\hline & Number & Mean & Min & Max & Standard Deviation & Difference FR-US \\
\hline \multicolumn{7}{|l|}{ Tobin's Q } \\
\hline FR & 1431 & 1.542 & 0.920 & 11.690 & 0.920 & \multirow{2}{*}{$-0.538^{* * *}$} \\
\hline US & 1827 & 2.080 & 0.643 & 10.681 & 1.168 & \\
\hline \multicolumn{7}{|c|}{ Equity.Comp } \\
\hline$F R$ & 1431 & 0.303 & 0 & 3.164 & 0.464 & \multirow{2}{*}{$-1.208^{\star \star *}$} \\
\hline US & 1827 & 1.511 & 0 & 4.504 & 0.831 & \\
\hline \multicolumn{7}{|c|}{ Manag.Owner\% } \\
\hline FR & 1431 & 16.338 & 0 & 97.33 & 23.365 & \multirow{2}{*}{$4.161^{\star * *}$} \\
\hline US & 1827 & 12.177 & 0 & 89.34 & 20.072 & \\
\hline \multicolumn{7}{|l|}{ Bd.Index } \\
\hline FR & 1431 & 18.287 & 4 & 32 & 5.772 & \multirow{2}{*}{$-10.630^{* \star *}$} \\
\hline US & 1827 & 28.917 & 9 & 34 & 4.491 & \\
\hline \multicolumn{7}{|l|}{ Size } \\
\hline FR & 1431 & 7.268 & 1.656 & 11.875 & 2.089 & \multirow{2}{*}{$-0.415^{\star \star \star}$} \\
\hline US & 1827 & 7.684 & 1.656 & 12.3338 & 2.132 & \\
\hline \multicolumn{7}{|l|}{ Lev } \\
\hline $\mathrm{FR}$ & 1431 & 0.245 & 0 & 1.669 & 0.182 & \multirow{2}{*}{$0.016^{\star * *}$} \\
\hline US & 1827 & 0.229 & 0 & 1.440 & 0.165 & \\
\hline \multicolumn{7}{|l|}{ Volat } \\
\hline FR & 1431 & 0.0261 & 0.006 & 0.293 & 0.020 & \multirow[t]{2}{*}{$0.0034^{* * *}$} \\
\hline US & 1827 & 0.0227 & 0.007 & 0.134 & 0.013 & \\
\hline \multicolumn{7}{|c|}{ Owner.Concent \% } \\
\hline$F R$ & 1431 & 44.92 & 0 & 99.1 & 23.02 & \multirow{2}{*}{$26.34^{* \star *}$} \\
\hline $\begin{array}{l}\text { US } \\
\text { Institu \% }\end{array}$ & 1827 & 18.58 & 0 & 96.87 & 14.69 & \\
\hline FR & 1431 & 61.25 & 0 & 99.1 & 27.97 & \multirow{2}{*}{$22.83^{\star \star \star}$} \\
\hline US & 1827 & 38.42 & 0 & 99.8 & 27.90 & \\
\hline
\end{tabular}

The table presents descriptive statistics for the 159 French companies and 203 U.S. companies for the period of 9 years from 2002 to 2010. Tobin's Q ((Market equity value + Book value of equity - Book value of total assets) / Book value of total assets), Equity.Comp: The natural logarithm of $(1+$ values of stock options and restricted stock received by the manager in year $\mathrm{t}$ ), Manag.Owner\%: The percentage of shares held by the manager, Bd.Index: The sum of scores for each company, Size: Natural logarithm of total assets, Lev: The ratio of total debt to total assets, Volat: The standard deviation of stock returns ,Owner.Concent: The percentage of shares held by the top three shareholders, Institu: The percentage of shares held by institutional investors.

For the variable measuring firm's performance (Tobin's $Q$ ), it presents respectively for the French and American cases 1.54 and 2.08. This proxy is slightly less compared to the results of Cui and Mak (2002), Doukas et al. (2005) and Chen et al. (2012) who found a Tobin's Q respectively equal to 2.86, 2.47 and 2.71 .

It is noted that most US companies reward their managers in the form of equity-based compensation from its French counterpart. In fact, the mean difference is due to legal reasons. This compensation component has been entered into force in the package manager in the French case recently relative to American context. The enactment of NRE 2001 and the Finance Act 2005, which respectively allow the award of stock options and restricted stock for the French manager.

At the score board, American firms recorded a mean score of 28.92 against 18.29 for French companies. This difference in averages is explained in legislature. Indeed, for the United States, the enactment of the Sarbanes-Oxley Act in 2002 that requires U.S. companies to follow a set of recommendations to ensure a better functioning of board to 
monitor the manager. Contrary to the French case the recommendations emitted by the AEFP / MEDEF for good governance practice within the firm does not have the regulatory character after 2008 that is to say, after the enactment of Law No. 2008-649, which requires the implementation of recommendations of the Code AEFP / MEDEF.

As for variables measuring ownership concentration and the institutional investors, there is a difference explained by divergence in the structure of ownership for both markets. The U.S. market is characterized by a dispersed ownership unlike the French market, which is concentrated in the ownership structure (A difference in average for the variable measuring the ownership concentration is $26.34 \%$ ). In addition, these two markets belong to two different systems of governance where in the French case, the officer control is done with institutional investors, which explains the high percentage of this type of investors in this market compared to the U.S. case (A difference in average is $22.83 \%$ ).

At the level of the variables: Size, Lev and Volat, respectively measuring the size of the firm's, leverage and volatility of stock returns, we observe that there is not much difference for the two samples.

Tables 2 and 3 show the Pearson correlation matrix for the variables used for the French and American companies. We notice that the coefficients between variables for the two cases are rather weak and we can deduce the absence of multicollinearity problem.

Table 2: Correlation matrix of Pearson (French companies)

\begin{tabular}{|c|c|c|c|c|c|c|c|c|c|c|}
\hline & & 1 & 2 & 3 & 4 & 5 & 6 & 7 & 8 & 9 \\
\hline 1 & Tobin's Q & 1 & & & & & & & & \\
\hline 2 & Equity.Comp & $0.0421^{* *}$ & 1 & & & & & & & \\
\hline 3 & Manag.Owner & $0.0779^{* * *}$ & $-0.0414^{*}$ & 1 & & & & & & \\
\hline 4 & Bd.Index & $0.0939^{* * *}$ & $0.0960^{* * *}$ & $-0.0853^{\star * *}$ & 1 & & & & & \\
\hline 5 & Size & $-0.1007^{\star \star *}$ & $0.0499^{\star \star}$ & 0.0231 & 0.0010 & 1 & & & & \\
\hline 6 & Lev & $-0.2570^{\star \star \star}$ & $-0.0709^{\star \star \star}$ & $-0.0473^{* *}$ & -0.0102 & $0.0639^{* * *}$ & 1 & & & \\
\hline 7 & Volat & 0.0082 & 0.0049 & 0.0185 & $-0.1230^{\star \star *}$ & -0.0035 & -0.0090 & 1 & & \\
\hline 8 & Owner.Concent & -0.0087 & -0.1481 & $0.0420^{*}$ & $-0.1440^{\star * *}$ & 0.0090 & $0.0756^{\star \star \star}$ & 0.0232 & 1 & \\
\hline 9 & Institu & $0.1233^{\star * *}$ & 0.0001 & 0.0292 & -0.0227 & $-0.0818^{\star \star *}$ & $-0.0571^{\text {** }}$ & $0.0524^{* *}$ & 0.0374 & 1 \\
\hline
\end{tabular}

The table presents the correlation coefficients between the variables selected for a sample of 159 French firms for the period from 2002 to 2010.

Table 3: Correlation matrix of Pearson (U.S. companies)

\begin{tabular}{|c|c|c|c|c|c|c|c|c|c|c|}
\hline & & 1 & 2 & 3 & 4 & 5 & 6 & 7 & 8 & 9 \\
\hline 1 & Tobin's Q & 1 & & & & & & & & \\
\hline 2 & Equity.Comp & $0.0369^{* *}$ & 1 & & & & & & & \\
\hline 3 & Manag.Owner & $0.0360^{\star \star}$ & $-0.2934^{* * *}$ & 1 & & & & & & \\
\hline 4 & Bd.Index & $0.0244^{* \star}$ & $-0.0111^{* * *}$ & $0.1167^{\star * *}$ & 1 & & & & & \\
\hline 5 & Size & $-0.3097^{* * *}$ & $0.4392^{* * *}$ & $-0.3918^{* * *}$ & $-0.0697^{* * *}$ & 1 & & & & \\
\hline 6 & Lev & $-0.1823^{\star \star \star}$ & -0.0144 & $-0.0710^{\star * *}$ & -0.0341 & $0.1903^{\star * *}$ & 1 & & & \\
\hline 7 & Volat & 0.0333 & 0.0348 & -0.0251 & $-0.1112^{\star \star *}$ & $-0.0917^{\star \star *}$ & $0.0585^{\star *}$ & 1 & & \\
\hline 8 & Owner.Concent & 0.0050 & $-0.3176^{* * *}$ & $0.4208^{\star * *}$ & 0.0011 & $-0.3091^{* * *}$ & $-0.0456^{*}$ & $-0.0567^{\star *}$ & 1 & \\
\hline 9 & Institu & $-0.0977^{* * *}$ & 0.0322 & $-0.1999 * * *$ & $0.0592^{* *}$ & $0.1758^{\star * *}$ & $0.1707^{\star \star *}$ & -0.0255 & -0.0803 & 1 \\
\hline
\end{tabular}

The table presents the correlation coefficients between the variables selected for a sample of 203 U.S. companies for the period from 2002 to 2010.

It shows that the company performance measured by Tobin's $Q$ is positively associated with managerial ownership and effectiveness of the board as measured by the variable (Bd.Index) regardless of the sample selected. In addition, the correlation between the variables (Bd.Index) and (Manag.Owner) is negative in the French case, confirming the hypothesis of substitution between governance mechanisms, unlike the U.S. case where it has been found a positive correlation between these two variables.

Tables 4 and 5 present the distribution of samples by percentage of shares held by the manager, following the French and American market. We note that over $60 \%$ of the number of observations (Company / Year) belong to the interval where the managerial ownership is between $0 \%$ and $10 \%$. In addition, these tables show a non-linear relationship 
between Tobin's $Q$ and managerial ownership for the French and American cases. Indeed, from Table 4, which corresponds to the French case, we see an increase of Tobin's $Q$ to the interval $[50 \%, 60 \%]$ where the proxy begins to decrease.

Table 4: Distribution of the sample of French companies by percentage of managerial ownership

\begin{tabular}{|lccccc|}
\cline { 2 - 5 } \multicolumn{1}{c|}{} & $\mathrm{N}$ & Tobin's Q & Equity.Comp & Bd.Index \\
\hline $0 \% \leq_{\text {Manag.Owner }<10 \%}$ & 879 & 1.5038 & 0.3706 & 19.5961 \\
$10 \% \leq_{\text {Manag.Owner }<20 \%}$ & 122 & 1.50810 & 0.1751 & 17.5 \\
$20 \% \leq_{\text {Manag.Owner }<30 \%}$ & 89 & 1.6026 & 0.1315 & 15.1236 \\
$30 \% \leq_{\text {Manag.Owner }<40 \%}$ & 49 & 1.6377 & 0.1025 & 15 \\
$40 \% \leq_{\text {Manag.Owner }<50 \%}$ & 62 & 1.7779 & 0.0175 & 15.5968 \\
$50 \% \leq_{\text {Manag.Owner }<60 \%}$ & 117 & 2.0422 & 0.3094 & 14.2245 \\
$60 \% \leq_{\text {Manag.Owner }<70 \%}$ & 50 & 1.4900 & 0.369 & 17.8889 \\
$70 \% \leq_{\text {Manag.Owner }<80 \%}$ & 60 & 1.4524 & 0.438 & 17.9333 \\
$80 \% \leq_{\text {Manag.Owner }<90 \%}$ & 2 & 1.3250 & 0.734 & 20.5 \\
$90 \% \leq_{\text {Manag.Owner }<100 \%}$ & 1 & 0.9295 & 0.742 & 19 \\
\hline
\end{tabular}

The table presents the distribution of the sample of French companies by percentage of managerial ownership where we give for each interval the number of observations $(\mathrm{N})$, the means of Tobin's $\mathrm{Q}$ (Tobin's $\mathrm{Q}$ ), equity based compensation (Equity.Comp) and the score board (Bd.Index).

Table 5, we can detect that there are two extreme points (minimum in the region $[30 \%, 40 \%]$ and Maximum in the region $[60 \%, 70 \%]$ in accordance with the observations of Davies et al. (2005).

Table 5: Distribution of the sample of U.S. companies by percentage of managerial ownership

\begin{tabular}{|lccccc|}
\cline { 2 - 5 } \multicolumn{1}{c|}{} & $\mathrm{N}$ & Tobin's Q & Equity.Comp & Bd.Index \\
\hline $0 \% \leq_{\text {Manag.Owner }<10 \%}$ & 1178 & 2.0444 & 1.6520 & 29.0696 \\
$10 \% \leq_{\text {Manag.Owner }<20 \%}$ & 249 & 2.1003 & 1.6040 & 28.5224 \\
$20 \% \leq_{\text {Manag.Owner }<30 \%}$ & 134 & 2.0279 & 1.5725 & 28.2125 \\
$30 \% \leq_{\text {Manag.Owner }<40 \%}$ & 80 & 1.9385 & 1.5568 & 26.625 \\
$40 \% \leq_{\text {Manag.Owner }<50 \%}$ & 48 & 1.9947 & 1.5374 & 25.75 \\
$50 \% \leq_{\text {Manag.Owner }<60 \%}$ & 41 & 2.4156 & 1.5070 & 26.3667 \\
$60 \% \leq_{\text {Manag.Owner }<70 \%}$ & 30 & 3.7544 & 1.0526 & 24.4900 \\
$70 \% \leq_{\text {Manag.Owner }<80 \%}$ & 33 & 2.7347 & 1.3660 & 28.5 \\
$80 \% \leq_{\text {Manag.Owner }<90 \%}$ & 30 & 2.5395 & 1.4507 & 29.0606 \\
$90 \% \leq_{\text {Manag.Owner }<100 \%}$ & 4 & 2.1138 & 1.4826 & 28.7561 \\
\hline
\end{tabular}

The table presents the distribution of the sample of U.S. companies by percentage of managerial ownership where we give for each interval the number of observations $(\mathrm{N})$, the means of Tobin's $Q$ (Tobin's $Q$ ), equity based compensation (Equity.Comp) and the score board (Bd.Index).

For (Equity.Comp) and (Bd.Index) variables, we see that for both cases they decrease to a some level of 
managerial ownership corresponding to intervals [60\%, $70 \%$ ] for U.S. firms and [ $40 \% 50 \%$ ] for French companies. These two regions correspond to the maximum value of Tobin's $Q$ then these results are consistent with the theoretical motivation where we assume the substitutability mechanism of manager controls.

\subsection{Multivariate analysis}

\subsubsection{Managerial ownership / Performance}

Table 6 presents the results of equation (1) to test the relationship between performance and managerial ownership 3 .

First, we notice that for the two samples, the result related to model 1 and 6 shows a positive and statistically significant relationship at $1 \%$ for the U.S. case and $5 \%$ for the French case. This confirms the agency theory, which states that the managerial ownership is a means to align the interests of executives with those of shareholders, which leads to an improved performance (Jensen and Meckling, 1976).

Then, for columns 2 and 7, we examine the non-linear relationship between managerial ownership and firm performance by including the square term of managerial

ownership $(k=2)$. The results for the two cases provide strong support for both the alignment of interest hypothesis and the hypothesis of entrenchment. In fact, we found statistically significant coefficients for the variables (Manag.Owner) and (Manag.Owner)2.

In particular, the results show that managerial ownership / performance curve is "inverted U-shaped" according to the results found by McConnell and Servaes (1990), Chen and Steiner (2000), and Florackis et al. (2009) and Chen et al. (2012). The performance reaches a maximum level for managerial ownership, which corresponds to $21 \%{ }^{4}$ for the U.S case and $57 \%{ }^{5}$ for the French case.

For $k=4$ (column 4 and column 9), we find the coefficients that correspond to variables (Manag.Owner), (Manag.Owner) $^{2}$, (Manag.Owner) ${ }^{3}$ and (Manag.Owner) ${ }^{4}$ statistically significant only in the American context at $1 \%$, according to the studies of Himmelberg et al. (1999) and Hu and Zhou (2008).

The quadratic relationship is not available in the French context, this is due of a high levels of ownership concentration. Therefore, the French manager can only be expropriated after the holding of a major proportion of firm share that can completely control the company (over 50\%). In contrast, in the American case where ownership structure is much dispersed, managerial entrenchment may be realize not only with high percentages of shares (over $50 \%$ ) but also at low levels of capital. In the American case, there are three critical points at level of $11 \%, 48 \%$ and $61 \%{ }^{6}$ (Alignment - Entrenchment - Alignment - Entrenchment).

For low level of managerial ownership [0\%, 11\%], the internal and external governance mechanisms are more effectively to control manager (Fama (1980), Morck et al. (1988) and Hermalin and Weisbach (1991)). In addition, according to Davies et al. (2005) in the situation (A small percentage of managerial ownership), a grant of stock options or restricted stock is necessary to encourage the manager to create value by tying his wealth with those of shareholders.

\footnotetext{
${ }^{3}$ We perform the test for homogeneity or we found the presence of a specific effect. In order to discriminate between the fixed effect and random effect we perform the Hausman test, which advocates that we must adopt the fixed effect model.

${ }^{4}$ The estimated model is: Tobin's $Q=3.21+0.0069^{*}$ Manag. Owner $-1.58^{*} 10^{-4 *}$ Manag. Owner ${ }^{2}+0.13^{*}$ Size $-0.034^{*}$ Lev $-5.92^{*}$ Volat. The maximum is obtained by the derivative of this equation with respect to the variable (Manag. Owner) and putting it equal to 0 .

${ }^{5}$ The estimated model is: Tobin's $Q=3.82+0.0111^{*}$ Manag. Owner $-9.64^{*} 10^{-4 *}$ Manag. Owner ${ }^{2}+0.28^{*}$ Size $-0.28^{*}$ Lev $-1.38^{*}$ Volat. The maximum is obtained by the derivative of this equation with respect to the variable (Manag. Owner) and putting it equal to 0 .

${ }^{6}$ The estimated model is: Tobin's $Q=3.18+0.297^{*}$ Manag. Owner $-1.8^{*} 10^{-3 *}$ Manag. Owner ${ }^{2}+3.63^{*} 10^{-5 *}$ Manag. Owner ${ }^{3}-2.25^{*} 10$ ${ }^{*}$ Manag. Owner ${ }^{4}+0.13^{*}$ Size- $0.14^{*}$ Lev $-5.95^{*}$ Volat. The maximum is obtained by the derivative of this equation with respect to the variable (Manag. Owner) and putting it equal to 0 .
} 
Table 6: The result of the regression of the relationship between managerial ownership and firm performance

\begin{tabular}{|c|c|c|c|c|c|c|c|c|c|c|}
\hline & \multicolumn{5}{|c|}{ France (Tobin's Q) } & \multicolumn{5}{|c|}{ U.S. (Tobin's Q) } \\
\hline & $k=1$ & $\mathrm{k}=2$ & $k=3$ & $\mathrm{k}=4$ & $k=5$ & $k=1$ & $\mathrm{k}=2$ & $k=3$ & $\mathrm{k}=4$ & $k=5$ \\
\hline Constant & $\begin{array}{c}3.8050^{\star \star \star} \\
(12.86)\end{array}$ & $\begin{array}{c}3.8237^{\star \star \star} \\
(12.94)\end{array}$ & $\begin{array}{c}3.7517^{\star \star \star} \\
(12.51)\end{array}$ & $\begin{array}{c}3.7518^{* \star \star} \\
(12.43)\end{array}$ & $\begin{array}{c}3.7497^{\star \star *} \\
(12.44)\end{array}$ & $\begin{array}{c}3.2381^{\star \star \star} \\
(10.85)\end{array}$ & $\begin{array}{c}3.2095^{\star \star \star} \\
(10.81)\end{array}$ & $\begin{array}{c}3.2126^{\star \star \star} \\
(10.80)\end{array}$ & $\begin{array}{c}3.1847^{\star \star *} \\
(10.74)\end{array}$ & $\begin{array}{c}3.1901^{\star \star \star} \\
(10.75)\end{array}$ \\
\hline Size & $0.2820^{* \star *}$ & $\begin{array}{c}0.2825^{\star * \star} \\
(7.19)\end{array}$ & $\begin{array}{c}0.2795^{* * *} \\
(711)\end{array}$ & $-0.2796^{\star \star *}$ & $\begin{array}{c}0.2768^{* \star *} \\
(704)\end{array}$ & $\begin{array}{c}0.1372^{\star * \star} \\
(359)\end{array}$ & $\begin{array}{c}0.1299^{* * *} \\
(342)\end{array}$ & $\begin{array}{c}0.1300^{* * *} \\
(342)\end{array}$ & $\begin{array}{c}0.1262^{* * *} \\
(333)\end{array}$ & $\begin{array}{c}0.1263^{* * *} \\
(333)\end{array}$ \\
\hline Lev & $\begin{array}{c}-0.3002^{*} \\
(-1.86)\end{array}$ & $\begin{array}{c}-0.2890^{*} \\
(-1.79)\end{array}$ & $\begin{array}{c}-0.2923^{*} \\
(-1.81)\end{array}$ & $\begin{array}{c}-0.2923^{*} \\
(-1.81)\end{array}$ & $\begin{array}{c}-0.3116^{*} \\
(-1.93)\end{array}$ & $\begin{array}{c}-0.0503 \\
(-0.30)\end{array}$ & $\begin{array}{l}-0.0337 \\
(-0.20)\end{array}$ & $\begin{array}{c}-0.0357 \\
(-0.21)\end{array}$ & $\begin{array}{l}0.0141 \\
(0.08)\end{array}$ & $\begin{array}{l}0.0081 \\
(0.05)\end{array}$ \\
\hline Volat & $\begin{array}{c}-1.4108 \\
(-1.56)\end{array}$ & $\begin{array}{c}-1.3813 \\
(1.53)\end{array}$ & $\begin{array}{c}-1.4125 \\
(-1.56)\end{array}$ & $\begin{array}{c}-1.4124 \\
(1.56)\end{array}$ & $\begin{array}{c}-1.3878 \\
(-1.54)\end{array}$ & $\begin{array}{c}-6.0585^{\star \star \star} \\
(-4.31)\end{array}$ & $\begin{array}{c}-5.9202^{\star * *} \\
(-4.23)\end{array}$ & $\begin{array}{c}-5.9195^{\star \star \star} \\
(-4.23)\end{array}$ & $\begin{array}{c}-5.9580^{\star * \star} \\
(-4.27)\end{array}$ & $\begin{array}{c}-6.0000^{* \star *} \\
(-4.32)\end{array}$ \\
\hline Manag.Owner & $\begin{array}{c}0.0063^{* *} \\
(2.18)\end{array}$ & $\begin{array}{c}0.0111^{* \star *} \\
(2.99)\end{array}$ & $\begin{array}{l}0.0048 \\
(-0.81)\end{array}$ & $\begin{array}{l}0.0048 \\
(0.54)\end{array}$ & $\begin{array}{c}0.0191^{*} \\
(1.68)\end{array}$ & $\begin{array}{c}0.0031^{\star * *} \\
(3.04)\end{array}$ & $\begin{array}{c}0.0069^{\star \star *} \\
(2.69)\end{array}$ & $\begin{array}{l}0.0078 \\
(1.59)\end{array}$ & $\begin{array}{c}0.0297^{* * *} \\
(3.64)\end{array}$ & $\begin{array}{c}0.0381^{* * *} \\
(2.91)\end{array}$ \\
\hline Manag.Owner ${ }^{2}$ & & $\begin{array}{c}-9.64 e-5^{* \star} \\
(-2.05)\end{array}$ & $\begin{array}{c}-7.77 e-5^{* \star} \\
(-2.25)\end{array}$ & $\begin{array}{c}-7.77 \mathrm{e}-5^{\star *} \\
(-2.25)\end{array}$ & $\begin{array}{c}-6.77 e-5^{*} \\
(-1.94)\end{array}$ & & $\begin{array}{c}-1.58 \mathrm{e}-4^{* * *} \\
(-4.24)\end{array}$ & $\begin{array}{c}-1.94 \mathrm{e}-4 \\
(-1.10)\end{array}$ & $\begin{array}{c}-1.8 \mathrm{e}-3^{* * *} \\
(-3.58)\end{array}$ & $\begin{array}{c}-2.9 \mathrm{e}-3^{* *} \\
(-2.19)\end{array}$ \\
\hline Manag.Owner ${ }^{3}$ & & & $\begin{array}{c}1.25 \mathrm{e}-06 \\
(1.41)\end{array}$ & $\begin{array}{c}1.24 \mathrm{e}-06 \\
(0.27)\end{array}$ & $\begin{array}{c}2.87 e-5^{*} \\
(1.84)\end{array}$ & & & $\begin{array}{l}3.30 \mathrm{e}-7 \\
(-0.21)\end{array}$ & $\begin{array}{c}3.63 \mathrm{e}-5^{\star * *} \\
(3.35)\end{array}$ & $\begin{array}{c}7.15 \mathrm{e}-4 \\
(1.61)\end{array}$ \\
\hline Manag.Owner ${ }^{4}$ & & & & $\begin{array}{c}-5.25 \mathrm{e}-11 \\
(0.00)\end{array}$ & $\begin{array}{c}-6.41 \mathrm{e}-07^{* *} \\
(-1.98)\end{array}$ & & & & $\begin{array}{c}-2.25 \mathrm{e}-7^{\star * *} \\
(-3.35)\end{array}$ & $\begin{array}{c}-7.17 e-7 \\
(-1.18)\end{array}$ \\
\hline Manag.Owner ${ }^{5}$ & & & & & $\begin{array}{c}3.64 \mathrm{e}-09 \\
(0.09)\end{array}$ & & & & & $\begin{array}{c}2.35 \mathrm{e}-9 \\
(0.82)\end{array}$ \\
\hline $\mathrm{R}^{2}$ & 0.16 & 0.16 & 0.16 & 0.1 & 0.16 & 0.1 & 0.12 & 0. & 0.10 & 0.10 \\
\hline Ficher & 15.50 & 13.27 & 11.40 & 9.76 & 9.06 & 10.52 & 12.10 & 10.08 & 10.30 & 9.10 \\
\hline & 0.000 & 0.000 & 0.000 & 0.000 & 0.000 & 0.000 & 0.000 & 0.000 & 0.000 & 0.000 \\
\hline Observations & 1431 & 1431 & 1431 & 1431 & 1431 & 1827 & 1827 & 1827 & 1827 & 1827 \\
\hline
\end{tabular}

*** Significant at $1 \%,{ }^{* *}$ significant at $5 \%,{ }^{*}$ significant at $10 \%$

The table presents the results of the regression of the relationship between managerial ownership and firm performance (After the tests required, we chose the fixed effect model. We only present estimates of fixed effect model). Manag.Owner: The percentage of shares held by the manager, Manag.Owner: The square of the percentage of shares held by the manager, Manag.Owner ${ }^{3}$ : The cube of the percentage of shares held by the manager, Manag.Owner ${ }^{4}$ : The fourth power of the percentage of shares held by the manager, Manag.Owner 5 : the five power of the percentage of shares held by the manager, all other variables are defined in Table 1.

According to Denis et al. (1997) and Dahya et al. (2002), the intermediate level of managerial ownership [11\%, $48 \%$ ], a greater percentage of managerial ownership leads to greater power of the executive in the form of voting rights. The manager can take advantage of this situation by increasing personal wealth even at the expense of the firm's value.

For a level of managerial ownership between $48 \%$ and $61 \%$, the principal and agent's objectives become convergent. According to Franks et al. (2001) and Davies et al. (2005) in this case, the manager escapes the capital market discipline, but it is still subject to the discipline of block holders and institutional investors who have some control over the management officer's even at high levels managerial ownership.

Beyond $61 \%$, the management of the company is in the hands of the officer who is the sole owner then in this case, it is out-of-control (internal and external governance mechanisms). Indeed, with such participation, on the one hand, the likelihood of hostile takeover becomes zero (failure of external control) and secondly, the absence of holders in block (internal control failure) then the leader can take advantage of this situation to expropriate and maximize his personal wealth, but at the expense of the interests of minority shareholders Morck et al. (1988).

Another argument that explains the negative relationship between performance and a high level of managerial ownership is developed by Smith and Stulz (1985) and Chen and Lee (2010). They suggest that the degree of risk aversion is increasingly high relative to the share held by the executive, which can lead the potential agency problem of under-investment that has a negative impact on firm performance.

Finally, for $k=3$, we test whether the relationship between managerial ownership and performance is cubic (columns 3 and 8 ), but we did not find a significant relationship. This result was found in the case $k=5$. From these findings, we can reject the cubic and quantum relationship between these variables for the two samples.

In the following, we have verified that there is a non-linear relationship between managerial ownership and performance but in a different form for the two markets. This difference is mainly explained by a large difference in concentration of ownership across two countries.

In the following, we will take a quadratic model for the U.S. case and a square model for the French case. 


\subsubsection{Managerial ownership / Performance / Board of directors}

Table 7 presents the results of the piecewise linear model that examines the relationship between managerial ownership, board control and firm performance ${ }^{7}$.

Table 7: The result of piecewise regression of the relationship between managerial ownership, board monitoring and firm performance

\begin{tabular}{|c|c|c|}
\hline & France (Tobin's Q) & U.S. (Tobin's Q) \\
\hline Constant & $\begin{array}{c}3.2289^{* * *} \\
(7.35)\end{array}$ & $\begin{array}{l}1.7002^{\star \star \star} \\
(3.22)\end{array}$ \\
\hline Manag.Owner A & $0.0132^{* *}$ & $\begin{array}{c}0.0904^{* * *} \\
(345)\end{array}$ \\
\hline Manag.Owner ${ }_{B}$ & $\begin{array}{c}-0.0703^{*} \\
(-1.91)\end{array}$ & $\begin{array}{c}-0.0392^{* * *} \\
(-3.19)\end{array}$ \\
\hline Manag.Owner c & & $\begin{array}{c}0.0670^{* *} \\
(2.05)\end{array}$ \\
\hline Manag.Owner ${ }_{D}$ & & $\begin{array}{c}-0.0459^{*} \\
(-1.69)\end{array}$ \\
\hline Bd.Index & $\begin{array}{l}1.2632 \\
(1.46)\end{array}$ & $\begin{array}{l}1.9893^{\star * \star} \\
(2.92)\end{array}$ \\
\hline Manag. Owner A ${ }^{*}$ Bd.Index & $\begin{array}{c}-0.0376^{* * *} \\
(-3.21)\end{array}$ & $\begin{array}{c}-0.1206^{* * *} \\
(-3.40)\end{array}$ \\
\hline Manag. Owner B ${ }^{*}$ Bd.Index & $\begin{array}{c}0.1086^{*} \\
(1.66)\end{array}$ & $\begin{array}{c}0.0395^{* *} \\
(2.34)\end{array}$ \\
\hline Manag. Owner c * Bd.Index & & $\begin{array}{c}-0.0234^{* * *} \\
(-3.37)\end{array}$ \\
\hline Manag. Owner D * Bd.Index & & $\begin{array}{c}0.0700^{*} \\
(1.84)\end{array}$ \\
\hline Size & $\begin{array}{c}-0.2284^{* \star *} \\
(-4.05)\end{array}$ & $\begin{array}{l}0.031 \\
(0.53)\end{array}$ \\
\hline Lev & $\begin{array}{l}-0.2681 \\
(-0.72)\end{array}$ & $\begin{array}{r}-0.1767 \\
(-0.38)\end{array}$ \\
\hline Volat & $\begin{array}{l}-0.9816 \\
(-1.18)\end{array}$ & $\begin{array}{c}-11.0518 \\
(-1.49)\end{array}$ \\
\hline Size * Bd.Index & $\begin{array}{l}-0.1227 \\
(-1.18)\end{array}$ & $\begin{array}{l}0.2430 \\
(0.56)\end{array}$ \\
\hline Lev *Bd.Index & $\begin{array}{l}-0.1446 \\
(-0.20)\end{array}$ & $\begin{array}{l}0.0987 \\
(0.14)\end{array}$ \\
\hline Volat* Bd Index & -1.1939 & 9.4935 \\
\hline Volat* Bd.Index & $(-0.21)$ & $(0.94)$ \\
\hline$R^{2}$ & 0.16 & 0.12 \\
\hline Ficher & 6.77 & 15.00 \\
\hline Prob $>F$ & 0.000 & 0.000 \\
\hline Observations & 1431 & 1827 \\
\hline
\end{tabular}

*** Significant at $1 \%,{ }^{* *}$ significant at $5 \%,{ }^{*}$ significant at $10 \%$

The table presents the result of the piecewise regression of the relationship between managerial ownership, board monitoring and firm performance (After the effectuation the tests required, we chose the fixed effect model. We only present estimates of fixed effect model). Manag.Owner A, Manag.Owner, Manag.Owner $\mathrm{c}$ and Manag.Owner D are defined in section 4.2, all other variables are defined in Table 1.

The main conclusion derived from this table, on the one hand, the interaction of variables indicating the presence of managerial entrenchment (Manag.Owner $r_{B}$ and Manag.Owner ${ }_{D}$ ) and board effectiveness with the performance of the firm are positively significant for both samples. On the other hand, in the case of interest's alignment (Manag.Owner ${ }_{A}$ and Manag.Ownerc), the variables combined with the board effectiveness are negative and statistically significant at $1 \%$ for the American and French cases with firm's performance. The search results can be interpreted from the hypothesis of

${ }^{7}$ We apply the homogeneity test and Hausman test, and we chose the fixed effect model 
substitutability of governance mechanisms previously developed by Denis and Sarin (1999) and Weir et al (2001).

Lasfer (2006) and Cheng et al. (2012) suggest that managerial ownership and board are two internal governance mechanisms to mitigate the agency problem between the principal and agent. Thus, if the managerial ownership leads to a convergence of interests and an increase in firm performance so there is a minimal follow-up by the board of directors (negative relationship between Manag.Owner ${ }_{A}$ (Manag.Ownerc) * Bd.Index and Tobin's Q).

Therefore, according to Cheng et al (2012) and referring to the hypothesis of substitutability between governance mechanisms, when the entrenchment effect is dominating, the authors assume that the board is effective in monitoring managerial entrenchment to mitigate agency conflicts that can appear (positive relationship between Manag.Owner (Manag.OwnerD) * Bd.Index and Tobin's Q).

In summary, regardless of the sample, in the case of the managerial entrenchment (a decrease of corporate performance) the board is a substitute for managerial ownership to mitigate the agency conflicts. However, in the alignment of interest there is less demand on the board to be effective to monitoring the manager.

\subsubsection{Managerial ownership / Board of directors / Managerial equity compensation}

Table 8 presents the results of the relationship between equity-based compensation received by the executive, managerial ownership and effectiveness of the board of directors. For the two samples, we note that firms distribute more than stock-based compensation in the case of managerial entrenchment (positive and statistically significant relationship between the variables (Equity.Comp) and (Manag.Owner ${ }_{B}$ ) (Manag.Owner $)$ ). In contrast, in the case of interest alignment, companies have less award of stock options and restricted stock (negative and statistically significant relationship between equity-based compensation (Equity.Comp) and variables (Manag.OwnerA) (Manag.Ownerc).

Table 8: The result of piecewise regression of the relationship between managerial ownership, board monitoring and equity based compensation

\begin{tabular}{|c|c|c|}
\hline & France (Equity.Comp) & U.S. (Equity.Comp) \\
\hline Constant & $\begin{array}{c}0.1856 \\
(0.58)\end{array}$ & $\begin{array}{l}0.0582 \\
(0.12)\end{array}$ \\
\hline Manag.Owner A & $\begin{array}{c}-0.0075^{\star \star *} \\
(-3.06)\end{array}$ & $\begin{array}{c}-0.0352^{* *} \\
(235)\end{array}$ \\
\hline Manag.Owner B & $\begin{array}{c}0.0455^{\star * *} \\
(3.79)\end{array}$ & $\begin{array}{c}0.0160^{*} \\
(1.67)\end{array}$ \\
\hline Manag.Ownerc & & $\begin{array}{c}-0.0450^{*} \\
(1.81)\end{array}$ \\
\hline Manag.Owner D & & $\begin{array}{c}0.060^{* *} \\
(2.23)\end{array}$ \\
\hline Bd.Index & $\begin{array}{r}-0.3497 \\
(-0.53)\end{array}$ & $\begin{array}{r}-0.3030 \\
(-0.52)\end{array}$ \\
\hline Manag.Owner A * Bd.Index & $\begin{array}{l}0.1433 \\
(0.37)\end{array}$ & $\begin{array}{l}0.0591 \\
(0.32)\end{array}$ \\
\hline Manag.Owner ${ }_{B}{ }^{*}$ Bd.Index & $\begin{array}{c}-0.0675^{\star \star \star} \\
(-2.99)\end{array}$ & $\begin{array}{c}-0.0971^{* *} \\
(-2.22)\end{array}$ \\
\hline Manag. Owner c ${ }^{*}$ Bd.Index & & $\begin{array}{c}-0.0822 \\
(-0.11)\end{array}$ \\
\hline Manag.Owner ${ }^{*}$ * Bd.Index & & $\begin{array}{c}-0.0771^{* *} \\
(-2.06)\end{array}$ \\
\hline Size & $\begin{array}{c}0.0595^{*} \\
(1.76)\end{array}$ & $\begin{array}{c}0.2280^{* * *} \\
(5.85)\end{array}$ \\
\hline Lev & $\begin{array}{c}-0.0756 \\
(-0.36)\end{array}$ & $\begin{array}{l}-0.693 \\
(-1.42)\end{array}$ \\
\hline Tobin's Q & -0.0650 & $0.3470^{* * *}$ \\
\hline & $(-1.63)$ & (3.16) \\
\hline Owner.Concent & $\begin{array}{c}-0.0259 \\
(-0.11)\end{array}$ & $\begin{array}{c}0.0913 \\
(0.10)\end{array}$ \\
\hline Institu & $\begin{array}{c}-0.3062 \\
(-1.50)\end{array}$ & $\begin{array}{l}0.0115 \\
(0.87)\end{array}$ \\
\hline Size *Bd.Index & -0.0201 & $0.0514^{* *}$ \\
\hline & $(-0.32)$ & (2.50) \\
\hline
\end{tabular}




\begin{tabular}{|c|c|c|}
\hline & France (Equity.Comp) & U.S. (Equity.Comp) \\
\hline Lev * Bd.Index & $\begin{array}{r}-0.4097 \\
(-1.00)\end{array}$ & $\begin{array}{c}0.0591^{*} \\
(1.76)\end{array}$ \\
\hline Tobin's $Q$ * Bd.Index & $0.2909^{* * *}$ & $-0.3583^{* *}$ \\
\hline Tovins Q Da.muex & $(2.90)$ & $(-2.48)$ \\
\hline Owner.Concent * Bd.Index & -0.1071 & -0.4950 \\
\hline Institu* Bd.Index & $\begin{array}{l}(-0.23) \\
0.0101^{*}\end{array}$ & $\begin{array}{l}(-0.41) \\
13150^{* *}\end{array}$ \\
\hline & $(1.84)$ & $(2.25)$ \\
\hline & 0.07 & 0.04 \\
\hline Ficher & 5.89 & 3.87 \\
\hline Prob $>F$ & 0.000 & 0.000 \\
\hline Observations & 1431 & 1827 \\
\hline
\end{tabular}

*** Significant at $1 \%,{ }^{* *}$ significant at $5 \%,{ }^{*}$ significant at $10 \%$

The table presents the result of the piecewise regression of the relationship between managerial ownership, board monitoring and equity based compensation (After the effectuation the tests required, we chose the fixed effect model. We only present estimates of fixed effect model). Manag.Owner A, Manag.Owner B, Manag.Owner $C$ and Manag.Owner $D$ are defined in section 4.2, all other variables are defined in Table 1.

Contrary to the prediction of agency theory and the majority of previous studies such as Mehran (1995), Ofek and Yermack (2000), Nagar and Rajan (2005) and Low (2009) who assume that the manager holds more share, these interests become aligned with shareholders and consequently, there is less need to grant equity-based compensation. Our results reject the hypothesis that the agency theory predicts a decreasing linear relationship between the percentage of shares held by the manager and the total of equity compensation granted to the officer. We argue here that equitybased compensation awards depends on the alignment of interests and the managerial entrenchment (non-linear relationship).

In fact, according to Daily et al. (2003) and Raedy and Wilson (2012), equity-based compensation is a way to align managers and shareholders' interests. On the one hand, the alignment interest effect exists, the award of such compensation is unlikely. On the other hand, in the case of managerial entrenchment, it is an existence of agency problems (Florackis and Ozkan, 2009) which will be mitigated by the attribute of the stock option and restricted stock.

For combined variables measuring the impact of board effectiveness and managerial ownership (case of alignment of interests and managerial entrenchment) and equity-based compensation. On the one hand, a negative and statistically significant relationship is seen between the variables Manag.Owner ${ }_{B}{ }^{*} B d$.Index and Manag.OwnerD ${ }^{*} B d$.Index (managerial entrenchment) and the endogenous variable Equity.Comp. On the other hand, in the case of the alignment of interest (Manag.Owner ${ }_{A}^{*} B d$.Index and Manag.Ownerc ${ }^{*} B d$.Index), a non-significant (neutral) relationship was detected between these variables and equity-based compensation.

One can interpret these results found based on the findings of John and Senbet (1998) and Aguilera et al. (2008), who assume that if the managerial entrenchment dominates, the behavior of the manager to expropriate (take advantage of stock based compensation) will be mitigated by effective board monitoring (substitute hypothesis among different governance mechanisms).

However, when the alignment of interests of managerial ownership is so dominant, a weak allocation of stockbased compensation as a way to align the interests between the principal and the agent for the benefit of the manager. Then the board will not impact to control the level of CEO compensation in this case.

In general, in the case of managerial entrenchment, the board is effective to substitute the dysfunction caused by the managerial ownership, which reduces the probability of award of equity-based compensation as a means of aligning interests of principal and agent.

\section{Endogeneity Problem}

The central issue in the majority of empirical studies is to determine the causal links between managerial ownership and firm performance (Cho (1998), Davies et al. (2005) and Ruan et al. (2011)).

Anderson et al. (2000) assume that the agency theory postulates that there exists a simultaneous relationship between performance and the level of CEO pay in particular, the awarding of equity-based compensation. Demsetz and Lehn (1985) argue that managerial ownership is endogenous to the specific characteristics of firms.

So, we follow the same methodology as $\mathrm{Ng}$ (2005) and Cheng et al. (2012) by applying the system of simultaneous 
equations ${ }^{8}$ to capture multiple potential relationships between managerial ownership, board of directors' efficiency and equity-based compensation.

Hence the model to be estimated is as follows:

For the French case:

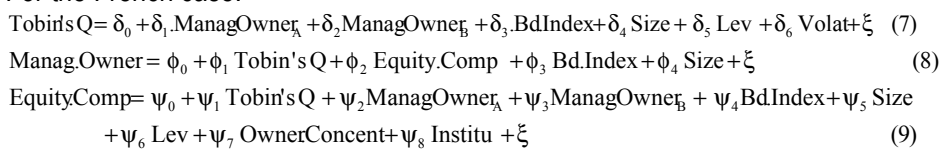

For the American case:

Tobin's $Q=\delta_{0}+\delta_{1}$ ManagOwner $_{A}+\delta_{2}$ ManagOwner $_{B}+\delta_{3}$ ManagOwnę $+\delta_{4}$ ManagOwner $+\delta_{5}$. Bd.Index $+\delta_{6}$ Size $+\delta_{7}$ Lev $+\delta_{8}$ Volat $+\xi$

Manag.Owner $=\phi_{0}+\phi_{1}$ Tobin's $Q+\phi_{2}$ Equity.Comp $+\phi_{3}$ Bd.Index $+\phi_{4}$ Size $+\xi$

Equity.Comp $=\psi_{0}+\psi_{1}$ Tobin's $Q+\psi_{2}$ Manag.Owner $_{\mathrm{A}}+\psi_{3}$ Manag.Owner $_{\mathrm{B}}$ $+\psi_{4}$ Manag.Owner ${ }_{\mathrm{C}}+\psi_{5}$ Manag.Owner $\mathrm{D}_{\mathrm{D}}+\psi_{6}$. Bd.Index $+\psi_{7}$ Size $+\psi_{8}$ Lev $+\psi_{9}$ Owner.Concent $+\psi_{10}$ Institu $+\xi$

To estimate this model, we chose to apply the 3SLS method because it takes into account the dependency between the error terms so unlike the 2SLS method to estimate each equation separately, this method allows simultaneous estimation of predefined equations.

Table 9 presents the results of the simultaneous equation, we observe that regardless of the sample used, there is a statistically significant relationship at the $1 \%$ threshold for different levels of managerial ownership (Manag.Owner $\mathrm{A}_{\mathrm{A}}$ Manag.Owners, Manag.Ownerc and Manag.OwnerD) with variable Tobin's Q (column 1 and 4).

This result is consistent with the postulates of the agency theory and the entrenchment theory that assume the managerial ownership is a governance mechanism that allows to affect firm's performance (In this case, the performance is determined by the managerial ownership (exogenous variable)).

In the case where managerial ownership is an endogenous variable, we note that the results are inconclusive. We found a non-significant relationship between managerial ownership and Tobin's $Q$ for the French case (column 2) and a positive and statistically significant relationship at the $1 \%$ (column 5) in the American case.

The endogeneity hypothesis is validated only in the American case, this is consistent with the investigation of Cho (1998) and Davies et al. (2005), but this is not similar to the results found by Demsetz and Villalonga (2001) and Cheng et al. (2012).

Davies et al. (2005) explain the relationship of endogenous assuming that the manager has a tendency to hold shares in companies characterized by a high value in order to maximize his wealth, but hidden behind this behavior is to control such companies. In contrast to the French case where institutional investors and blockholders have an important role in monitoring the officer. Manager control in the American context is mainly through the capital market when a company characterized by a relatively high performance is a target for the manager to expropriate. Consequently, the manager tries to neutralize the main governance mechanism (capital market monitoring) by acquiring a large percentage of shares.

At the (Bd.Index) that measures the effectiveness of the board, a negative and statistically significant relationship was observed between this variable and managerial ownership for two cases which confirms that these two mechanisms are substitutable to ensure an alignment of interests between the manager and shareholders (Prevost et al. 2002).

For columns 3 and 6 , according to the result previously found that the awarding of equity compensation is a nonmonotonic function with managerial ownership. Earlier studies found a negative relationship between the equity-based compensation and managerial ownership in relying only on agency theory, which postulates that the alignment of interest is by the acquisition of large number of shares of the officer.

\footnotetext{
${ }^{8}$ We verified the conditions of order and rank. For order condition: The number of endogenous variables and excluded exogenous variables must be greater than or equal to the number of equations minus one. To rank condition: According to Greene (1997), which assumes that a system which meets the order conditions is extremely rare not fulfill the rank conditions. Therefore, our system is identifiable.
} 
Table 9: The analysis by the simultaneous equations between managerial ownership, firm performance and equity based compensation

\begin{tabular}{|c|c|c|c|c|c|c|}
\hline \multirow[b]{2}{*}{ Variables } & \multicolumn{3}{|c|}{ France } & \multicolumn{3}{|c|}{ U.S. } \\
\hline & $\begin{array}{l}\text { Tobin's Q } \\
\text { (model 7) }\end{array}$ & $\begin{array}{c}\text { Manag.Owner } \\
\text { (model 8) }\end{array}$ & $\begin{array}{l}\text { Equity.Comp } \\
\text { (model 9) }\end{array}$ & $\begin{array}{l}\text { Tobin's Q } \\
\text { (model10) }\end{array}$ & $\begin{array}{l}\text { Manag.Owner } \\
\text { (model 11) }\end{array}$ & $\begin{array}{l}\text { Equity.Comp } \\
\text { (model 12) }\end{array}$ \\
\hline Constant & $\begin{array}{c}2.9491^{* * *} \\
(25.10)\end{array}$ & $\begin{array}{c}51.5393^{* * *} \\
(16.78)\end{array}$ & $\begin{array}{l}-0.0008 \\
(-0.22)\end{array}$ & $\begin{array}{c}3.1801^{* * *} \\
(15.50)\end{array}$ & $\begin{array}{c}13.4382^{* * *} \\
(3.68)\end{array}$ & $\begin{array}{r}-0.0027 \\
(-0.60)\end{array}$ \\
\hline Manag.Owner & $\begin{array}{c}0.0060^{* * *} \\
(4.32)\end{array}$ & & $\begin{array}{c}-0.0037^{\star * \star} \\
(-5.62)\end{array}$ & $\begin{array}{c}0.0188^{\star \star *} \\
(3.09)\end{array}$ & & $\begin{array}{c}-0.1178^{\star \star \star} \\
(-7.08)\end{array}$ \\
\hline Manag. Owner ${ }_{B}$ & $\begin{array}{c}-0.0216^{* * *} \\
(-2.89)\end{array}$ & & $\begin{array}{c}0.0026^{* * *} \\
(3.88)\end{array}$ & $\begin{array}{c}-0.8197^{* * *} \\
(-3.63)\end{array}$ & & $\begin{array}{c}0.0062^{* * *} \\
(2.79)\end{array}$ \\
\hline Manag. Ownerc & & & & $\begin{array}{c}0.0503^{\star \star \star} \\
(6.99)\end{array}$ & & $\begin{array}{c}-0.0447^{* \star *} \\
(-2.65)\end{array}$ \\
\hline Manag.Owner D & & & & $\begin{array}{c}-0.0074^{* *} \\
(-2.52)\end{array}$ & & $\begin{array}{c}0.0759^{\star * *} \\
(5.76)\end{array}$ \\
\hline Bd.Index & $\begin{array}{c}-0.0994 \\
(-0.57)\end{array}$ & $\begin{array}{c}-3.6431^{* * *} \\
(-5.50)\end{array}$ & $\begin{array}{c}0.2627^{\star * *} \\
(3.22)\end{array}$ & $\begin{array}{l}0.0069 \\
(1.07)\end{array}$ & $\begin{array}{c}-8.4771^{* *} \\
(-2.09)\end{array}$ & $\begin{array}{l}0.0057 \\
(1.04)\end{array}$ \\
\hline Size & $\begin{array}{c}-0.1500^{* * *} \\
(-11.45)\end{array}$ & $\begin{array}{c}-3.2558^{\star * \star} \\
(-9.39)\end{array}$ & $\begin{array}{c}0.0794^{* * *} \\
(12.53)\end{array}$ & $\begin{array}{c}-0.0346^{* \star *} \\
(-2.83)\end{array}$ & $\begin{array}{c}0.3853^{*} \\
(1.75)\end{array}$ & $\begin{array}{c}0.0261^{* \star *} \\
(2.87)\end{array}$ \\
\hline Lev & $\begin{array}{c}0.6900^{* * *} \\
(5.15)\end{array}$ & $\begin{array}{c}-6.4468^{\star} \\
(-1.92)\end{array}$ & $\begin{array}{c}-0.1901^{* * *} \\
(-3.04)\end{array}$ & $\begin{array}{c}1.7834^{* * *} \\
(11.38)\end{array}$ & & $\begin{array}{c}-0.2973^{\star *} \\
(-2.46)\end{array}$ \\
\hline Volat & $\begin{array}{c}0.2985 \\
(0.26)\end{array}$ & & & $\begin{array}{l}0.1328 \\
(0.06)\end{array}$ & & \\
\hline Tobin's Q & & $\begin{array}{c}-2.3094 \\
(-0.53)\end{array}$ & $\begin{array}{c}0.0751^{* * *} \\
(6.17)\end{array}$ & & $\begin{array}{c}2.4293^{\star \star *} \\
(6.02)\end{array}$ & $\begin{array}{l}0.0262 \\
(1.51)\end{array}$ \\
\hline Equity.Comp & & $\begin{array}{c}-12.5527^{\star * \star} \\
(-9.10)\end{array}$ & & & $\begin{array}{c}-2.0747^{\star \star *} \\
(-3.68)\end{array}$ & \\
\hline Owner.Concent & & & $\begin{array}{c}-0.3301^{* * *} \\
(-6.40)\end{array}$ & & & $\begin{array}{c}-0.0040 \\
(-0.84)\end{array}$ \\
\hline Institu & & & $\begin{array}{c}-0.0916^{\star *} \\
(-2.33)\end{array}$ & & & $\begin{array}{l}0.0181 \\
(0.26)\end{array}$ \\
\hline $\mathrm{R}^{2}$ & 0.11 & 0.14 & 0.26 & 0.11 & 0.007 & 0.04 \\
\hline Observations & 1431 & 1431 & 1431 & 1827 & 1827 & 1827 \\
\hline
\end{tabular}

${ }^{* * *}$ Significant at $1 \%,{ }^{* *}$ significant at $5 \%,{ }^{*}$ significant at $10 \%$

The table presents the analysis of the simultaneous equations of managerial ownership, firm performance and equity based compensation by using the 3SLS method.

Therefore, managerial ownership is a decreasing function of the decision to award stock options or restricted stock. However, the non-monotony found in our study may be explained by the effect of managerial entrenchment, in which case the leader can benefit from equity-based compensation in order to reduce agency problems that may be born with the principal in this situation.

In addition, regardless of the sample selected, companies' large size and less leveraged pay their managers more in shares, in accordance with the results found by (Ryan and Wiggins III (2001) and Ushida (2006)).

We note that there is a negative relationship between the variables measuring the concentration of ownership and the presence of institutional investors, with the allocation of equity-based compensation in the French case. On the contrary, in the American case, these two variables are not significant. This result demonstrates the importance of these variables in the French case as a manager control mechanism relative to the U.S. case.

\section{Conclusion}

This study focuses on 159 French companies and 203 U.S. companies for the period from 2002 to 2010 where we found a non-linear inverted U-shaped relationship between managerial ownership and performance to the French case and a quadratic relationship for the U.S. case. This difference in the shape of the curve is due to the difference in the concentration of ownership.

Using these turning points that explain the effect of alignment or managerial entrenchment, we estimated a model of piecewise linear regression where we found that independent of the sample used in the case of managerial 
entrenchment, the board is a substitute for managerial ownership to solve the agency problem.

In addition, on the one hand, the equity-based compensation is non-linear function with managerial ownership in contrast to previous studies that assume a monotonous or non-significant relationship. On the other hand, referring to the substitution hypothesis, this study demonstrates the effectiveness of the board as a substitute for managerial ownership in the case of managerial entrenchment.

Given the importance of the problem of endogeneity of managerial ownership, we conducted a simultaneous equation where we found that the endogeneity hypothesis is verified only in the U.S case. This result leads us to believe that the American manager has a preference to hold a large percentage of shares of firms that performed well to neutralize the capital market monitoring, which is the principal governance mechanism for this type of firm. In contrast, the French manager monitoring by the capital market is not large enough (a major investor control institutional holders and blocks) which reduces the probability of this opportunistic behavior in this case.

Our study has some limitations that are worth mentioning. We have limited that the board has an effect on the control mechanism of the manager then it is interesting to see the impact of other internal and even outside governance mechanisms as an alternative to solve the problem of managerial entrenchment. As we mentioned before, the non-linear relationship between equity-based compensation and managerial ownership may conduct a study on the factors of stockbased compensation, taking into account alignment and divergence of interests.

\section{Reference}

Aguilera, R. V., Filatotchev, I., Gospel, H. and Jackson, G. (2008)."An organizational approach to comparative corporate governance: costs, contingencies, and complementarities" Organization Science Vol. 19 No. 3, pp. 475-492.

Anderson, R. C., Bates, W. B., Bizjak, J. M. and Lemmon, M. L. (2000)."Corporate governance and firm diversification" Financial Management Vol. 29 No. 1, pp. 5-22.

Bebchuk, L. and Fried, J. (2004)."Pay without Performance: The Unfulfilled Promise of Executive Compensation", Working Paper, Harvard University, Cambridge.

Berle, A. A. and Means, G. C. (1932). The modern corporation and private property, Transaction Publishers, New York.

Bhagata, S. and Bolton, B. (2008)."Corporate governance and firm performance" Journal of Corporate Finance, Vol. 14 No. 3, pp. 257273.

Black, F. and Scholes, M. (1973)."The pricing of options and corporate liabilities" Journal of Political Economy, Vol. 81 No. 3, pp. 637654.

Brown, L. D. and Lee, Y. J. (2010)."The relation between corporate governance and CEOs' equity grants" Journal of Accounting and Public Policy, Vol. 29 No. 6, pp. 533-558.

Chen, C. R. and Steiner, T. L. (2000)."Tobin's q, managerial ownership, and analyst coverage: A nonlinear simultaneous equations model" Journal of Economics and Business Vol. 54 No. 4, pp. 365-382.

Chen, M. H., Houb, C. L. and Lee, S. (2012)."The impact of insider managerial ownership on corporate performance of Taiwanese tourist hotels" International Journal of Hospitality Management, Vol. 31 No. 2, pp. 338-349.

Chen, Y. R. and Lee, B. S. (2010)."A dynamic analysis of executive stock options: Determinants and consequences" Journal of Corporate Finance Vol. 16 No. 1, pp. 88-103.

Cheng, P., Su, L. and Zhu, X. (2012)."Managerial ownership, board monitoring and firm performance in a family-concentrated corporate environment" Accounting and Finance, Vol. 52 No. 4, pp. 1061-1081.

Cho, M. H. (1998)."Ownership structure, investment, and the corporate value: An empirical analysis" Journal of Financial Economics Vol. 47 No. 1, pp. 103-121.

Core, J. E., Holthausen, R. W. and Larcker, D. (1999)."Corporate governance, chief executive officer compensation, and firm performance" Journal of Financial Economics Vol. 51 No. 3, pp. 371-406.

Cui, H. and Mak, Y. T. (2002)."The relationship between managerial ownership and firm performance in high R\&D firms" Journal of Corporate Finance, Vol. 8 No. 4, pp. 313-336.

Dahya, J., McConnell, J. J. and Travlos, N. G. (2002)."The Cadbury committee, corporate performance, and top management turnover" Journal of Finance, Vol. 57 No. 1, pp. 461-483.

Daily, C. M., Certo, S. T., Dalton, D. R. and Roengpitya, R. (2003)."IPO underpricing: A meta-analysis and research synthesis" Entrepreneurship Theory and Practice, Vol. 27 No. 3, pp. 271-295.

Davies, J. R., Hillier, D. and McColgan, P. (2005)."Ownership structure, managerial behavior and corporate value" Journal of Corporate Finance Vol. 11 No. 4, pp. 645-660.

DeAngelo, H. and DeAngelo, L. (1985)."Managerial ownership of voting rights: a study of public corporations with dual classes of common stock" Journal of Financial Economics, Vol. 14 No. 1, pp. 33-69.

Demsetz, H. and Lehn, K. (1985)."The structure of corporate ownership: causes and consequences" Journal of Political Economy Vol. 93 №. 6, pp. 1155-1177.

Demsetz, H. and Villalonga, B. (2001)."Ownership structure and corporate performance" Journal of Corporate Finance Vol. 7 No. 3, pp. $209-233$.

Denis, D. and Sarin, A. (1999)."Ownership and board structures in publicly traded corporations" Journal of Financial Economics Vol. 52 
No. 2, pp. 187-223.

Denis, D. J., Denis, D. and Sarin, A. (1997)."Ownership structure and top executive turnover" Journal of Financial Economics, Vol. 45 No. 2, pp. 193-221.

Doukas, J. A., McKnight, P. J. and Pantzalis, C. (2005)."Security analysis, agency costs, and UK firm characteristics" International Review of Financial Analysis Vol. 14 No. 5, pp. 493-507.

Drakos, A. A. and Bekiris, F. V. (2010)."Corporate performance, managerial ownership and endogeneity: A simultaneous equations analysis for the Athens stock exchange" Research in International Business and Finance Vol. 24 No. 1, pp. 24-38.

Fama, E. F. (1980)."Agency problems and the theory of the firm" Journal of Political Economy Vol. 88 No. 2, pp. 288-307.

Fama, E. F. and Jensen, M. C. (1983)."Agency problems and residual claims" Journal of Law and Economics, Vol. 26 No. 2, pp. $327-$ 349 .

Florackis, C., Kostakis, A. and Ozkan, A. (2009)."A Managerial ownership and performance," Journal of Business Research Vol. 62 No. 12, pp. 1350-1357.

Florackis, C. and Ozkan, A. (2009)."The impact of managerial entrenchment on agency costs: an empirical investigation using UK panel data" European Financial Management, Vol. 15 No. 3, pp. 497- 528.

Greene, W. H. (1997). Econometric analysis, Prentice Hall,

Guillet, B. D., Kucukusta, D. and Xiao, Q. (2012)."An examination of executive compensation in the restaurant industry" International Journal of Hospitality Management, Vol. 31 No. 1, pp. 86-95.

Hermalin, B. E. and Weisbach, M. S. (1991)."The effects of board composition and direct incentives on firm performance" Financial Management, Vol. 20 No. 4, pp. 101-112.

Hess, K., Gunasekarage, A. and Hovey, M. (2010)."State-dominant and non-state-dominant ownership concentration and firm performance: Evidence from China" International Journal of Managerial Finance Vol. 6 No. 4, pp. 264-289.

Himmelberg, C. P., Hubbard, R. G. and Palia, D. (1999)."Understanding the determinants of managerial ownership and the link between ownership and performance" Journal of Financial Economics, Vol. 53 No. 3, pp. 353-384.

Holderness, C. and Sheehan, D. (1991)."Monitoring an owner: the case of turner broadcasting" Journal of Financial Economics, Vol. 30 No. 2, pp. 325-346.

$\mathrm{Hu}, \mathrm{Y}$. and Izumida, S. (2008)."Ownership concentration and corporate performance: A causal analysis with Japanese panel data" Corporate Governance: An International Review, Vol. 16 No. 4, pp. 342-358.

$\mathrm{Hu}, \mathrm{Y}$. and Zhou, X. (2008)."The performance effect of managerial ownership: Evidence from China" Journal of Banking \& Finance, Vol. 32 No. 10, pp. 2099-2110.

Jackling, B. and Johl, S. (2009)."Board structure and firm performance: Evidence from india's top companies" Corporate Governance: An International Review Vol. 17 No. 4, pp. 492-509.

Jensen, M. C. and Meckling, W. H. (1976)."Theory of the firm: managerial behavior, agency costs and ownership structure" Journal of Financial Economics, Vol. 3 No. 4, pp. 305-360.

John, K. and Senbet, L. (1998)."Corporate governance and board effectiveness" Journal of Banking and Finance, Vol. 22 No. 4, pp. 371403.

Klapper, L. F. and Love, I. (2004)."Corporate governance, investor protection, and performance in emerging markets" Journal of Corporate Finance, Vol. 10 No. 5, pp. 703-726.

Lasfer, M. A. (2006)."The interrelationship between managerial ownership and board structure" Journal of Business Finance and Accounting Vol. 33 No. $7 / 8$, pp. 1006-1033.

Low, A. (2009)."Managerial risk-taking behavior and equity-based compensation" Journal of Financial Economics, Vol. 92 No. 3, pp. $470-490$.

Matsunaga, R. (1995)."The effects of financial reporting costs on the use of employee stock options" The Accounting Review Vol. 70 No. 1, pp. $1-26$.

Maury, B. (2006)."Family ownership and firm performance: Empirical evidence from Western European corporations" Journal of Corporate Finance, Vol. 12 No. 2, pp. 321-341.

McConnell, J. and Servaes, H. (1990)."Additional evidence on equity ownership and corporate value" Journal of Financial Economics, Vol. 24 No. 2, pp. 595-612.

Mehran, H. (1995)."Executive compensation structure, ownership, and firm performance" Journal of Financial Economics, Vol. 38 No. 2, pp. 163-184.

Morck, R., Shleifer, A. and Vishny, R. W. (1988)."Management ownership and market valuation: an empirical analysis" Journal of Financial Economics, Vol. 20 No. 1/2, pp. 293-315.

Nagar, V. and Rajan, M. V. (2005)."Measuring customer relationships: The case of the retail banking industry" Management Science, Vol. 51 No. 6, pp. 904-919.

$\mathrm{Ng}, \mathrm{C}$. Y. M. (2005)."An empirical study on the relationship between ownership and performance in a family-based corporate environment" Journal of Accounting, Auditing and Finance, Vol. 20 No. 2, pp. 121-146.

Ofek, E. and Yermack, D. (2000)."Taking stock: equity-based compensation and the evolution of managerial ownership" Journal of Finance, Vol. 55 No. 3, pp. 1367-1384.

Ozdemir, O. and Upneja, A. (2012)."Board structure and CEO compensation: Evidence from U.S. lodging industry" International Journal of Hospitality Management, Vol. 31 No. 3, pp. 856-863.

Ozkan, N. (2007)."Do corporate governance mechanisms influence CEO compensation? An empirical investigation of UK companies" Journal of Multinational Financial Management, Vol. 17 No. 5, pp. 349-364. 
Pathan, S. and Faff, R. (2013)."Does board structure in banks really affect their performance?" Journal of Banking \& Finance, Vol. 37 No. 5, pp. 1573-1589.

Prevost, A., Rao, R. and Hossain, M. (2002)."Board composition in New Zealand: An agency perspective" Journal of Business Finance and Accounting, Vol. 29 No. 5, pp. 731-760.

Raedy, J. and Wilson, W. (2012)."A simultaneous examination of the effects of reporting incentives on earnings properties", Working Paper, Southern Methodist University,Dallas.

Ruan, W., Tian, G. and Ma, S. (2011)."Managerial ownership, capital structure and firm value: Evidence from China's civilian-run Firms" Australasian Accounting Business and Finance Journal, Vol. 5 No. 3, pp. 73-92.

Ryan, H. E. and Wiggins III, R. A. (2001)."The influence of firm and manager specific characteristics on the structure of executive compensation" Journal of Corporate Finance, Vol. 7 No. 2, pp. 101-123.

Short, H. and Keasey, K. (1999)."Managerial ownership and the performance of firms: evidence from the UK" Journal of Corporate Finance, Vol. 5 No. 1, pp. 79-101.

Smith, C. and Stulz, R. M. (1985)."The determinants of firms' hedging policies" The Journal of Financial and Quantitative Analysis, Vol. 20 No. 4, pp. 391-405.

Tzioumis, K. (2008)."Why do firms adopt CEO stock options?" Journal of Economic Behavior \& Organization Vol. 68 No. 1, pp. $100-111$.

Uchida, K. (2006)."Determinants of stock option use by Japanese companies" Review of Financial Economics, Vol. 15 No. 3, pp. 251269.

Vafeas, N. and Theodorou, E. (1998)."The association between board structure and firm performance in the UK" British Accounting Review, Vol. 30 No. 4, pp. 383-407.

Van Essen, M., O., J. and Carberry, E. (2012)."Assessing managerial power theory: A meta-analytic approach to understanding the determinants of CEO compensation" Journal of Management, Vol. forthcoming No. pp.

Weir, C., Laing, D. and McKnight, P. (2002)."Internal and external governance mechanisms: Their impact on the performance of large UK public companies" Journal of Business Finance and Accounting, Vol. 29 No. 5/6, pp. 579-611.

Yermack, D. (1995)."Do corporation award CEO stock-options effectively?" Journal of Financial Economics, Vol. 39 No. 2/3, pp. 237269.

Yermack, D. (1996)."Higher market valuation of companies with a small board of directors" Journal of Financial Economics Vol. 40 No. 2 , pp. 185-211. 